\title{
Cascading nutrient limitation of the cyanobacterium Cylindrospermopsis raciborskii in a Sahelian lake (North Senegal)
}

\author{
P. Dufour ${ }^{1}$, G. Sarazin ${ }^{2, *}$, C. Quiblier ${ }^{3}$, S. Sane ${ }^{4}$, C. Leboulanger ${ }^{1}$ \\ ${ }^{1}$ IRD/INRA, Station d'Hydrobiologie Lacustre, BP 511, 74203 Thonon-les-Bains, France \\ ${ }^{2}$ Université Paris 7, Tour 53-54, CP 7052, 2 place Jussieu, 75251 Paris cedex 05, France \\ ${ }^{3}$ MNHN, Laboratoire de Cryptogamie, 12 rue Buffon, 75005 Paris, France \\ ${ }^{4}$ IRD, Centre de Bel Air, BP 1386, Dakar, Senegal
}

\begin{abstract}
Bioassays in natural water-based batch cultures were performed to identify factors that could control the development of the toxic heterocystous cyanobacterium Cylindrospermopsis raciborskii in Lake Guiers (North Senegal). Without dissolved inorganic nitrogen, C. raciborskii was unable to grow, unless EDTA was supplied. The addition of $\mathrm{P}, \mathrm{S}, \mathrm{Fe}, \mathrm{B}, \mathrm{Ca}, \mathrm{Co}, \mathrm{Cu}, \mathrm{Mg}, \mathrm{Mn}, \mathrm{Mo}$ and Zn did not restore its growth. Variations in the percentages of heterocysts found in bioassays, in the concentrations of major and trace elements in Lake Guiers, and in the computed chemical speciation of all dissolved species using MINEQL+ software, led us to deduce that, after N, Fe was the second greatest growth-limiting nutrient. Assuming that the 'Free Ion Model' is valid for the indigenous species of phytoplankton, the concentrations of bioavailable $\mathrm{Fe}^{3+}$ were within the range of $10^{-19}$ to $10^{-22}$ $\mathrm{M}$ and were limited by the very low solubility of Fe-hydroxides. At such negligible concentrations, $C$. raciborskii is unable to take up the Fe necessary to ensure efficient nitrogenase functioning. The addition of EDTA led to the production of (III) Fe-EDTA complexes, which acted as an iron buffer that, in turn, increased the bioavailability of $\mathrm{Fe}^{3+}$ and the growth of $C$. raciborskii. These bioassays suggest that, in Lake Guiers, the primary limiting factor for cyanobacterial growth is nitrogen. They also demonstrate the lack of a sufficient concentration of complexing agents, which limits the bioavailability of $\mathrm{Fe}$, and then the nitrogenase activity and diazotrophy of $C$. raciborskii. This cascading limitation could account for the seasonal fluctuations of this cyanobacterial population in Lake Guiers.
\end{abstract}

KEY WORDS: Diazotrophy · Fe bioavailability · Cyanobacteria $\cdot$ Cylindrospermopsis raciborskii • Senegal · Guiers Lake

Resale or republication not permitted without written consent of the publisher

\section{INTRODUCTION}

Lake Guiers is a shallow reservoir located in the northwestern part of Senegal $\left(16^{\circ} \mathrm{N}, 15.5^{\circ} \mathrm{W}\right)$, which was built in the early 1980 s on a southern temporary branch of the Senegal River. The lake water is used both for irrigating crops and as a drinking water resource for urban centers, including Dakar, the capital of Senegal, as well as for the local population and animal herds. The phytoplankton community structure is consistently dominated by the heterocystous cyanobacterium Cylindrospermopsis raciborskii (Cogels et al. 2001, Arfi et al. 2003, Berger et al. 2006, Ka et al. 2006). This species makes up about $25 \%$ of the yearround total phytoplankton biomass, but is often dominant from August to October. As this cyanobacterium is known to be potentially toxic (Hawkins et al. 1985, Bernard et al. 2003, Berger et al. 2006), it constitutes an obvious health hazard with regard to water use.

Cylindrospermopsis raciborskii has various ecological features that can account in part for its success in out-competing other species in contrasting environments and at various latitudes. This species was originally classified as tropical to subtropical, but its pres- 
ence has since been reported in several temperate areas (Padisák 1997, Gugger et al. 2005). This reflects the wide range of temperatures and light intensities it can tolerate, since it displays positive net growth at temperatures from 20 to $35^{\circ} \mathrm{C}$ and at light intensities from 30 to $500 \mu \mathrm{mol}$ photons $\mathrm{m}^{-2} \mathrm{~s}^{-1}$ (Briand et al. 2004); it also proves the fact that it has fatty acid protectants that enable it to tolerate oversaturating illumination (Várkonyi et al. 2000). Among other ecophysiological features, the species has a high affinity and storage capacity for phosphorus (Istvănovics et al. 2000), plus a functional nitrogenase activity that allows it to use dissolved molecular nitrogen as its sole $\mathrm{N}$ source (Spröber et al. 2003). Despite these competitive advantages, the biomass of C. raciborskii in Lake Guiers remains limited for most of the year, although it reaches $40 \%$ of total phytoplankton cell numbers and biovolumes during autumn. The absence of efficient zooplankton grazers of C. raciborskii in Lake Guiers (Ka et al. 2006) means that top-down control is unlikely

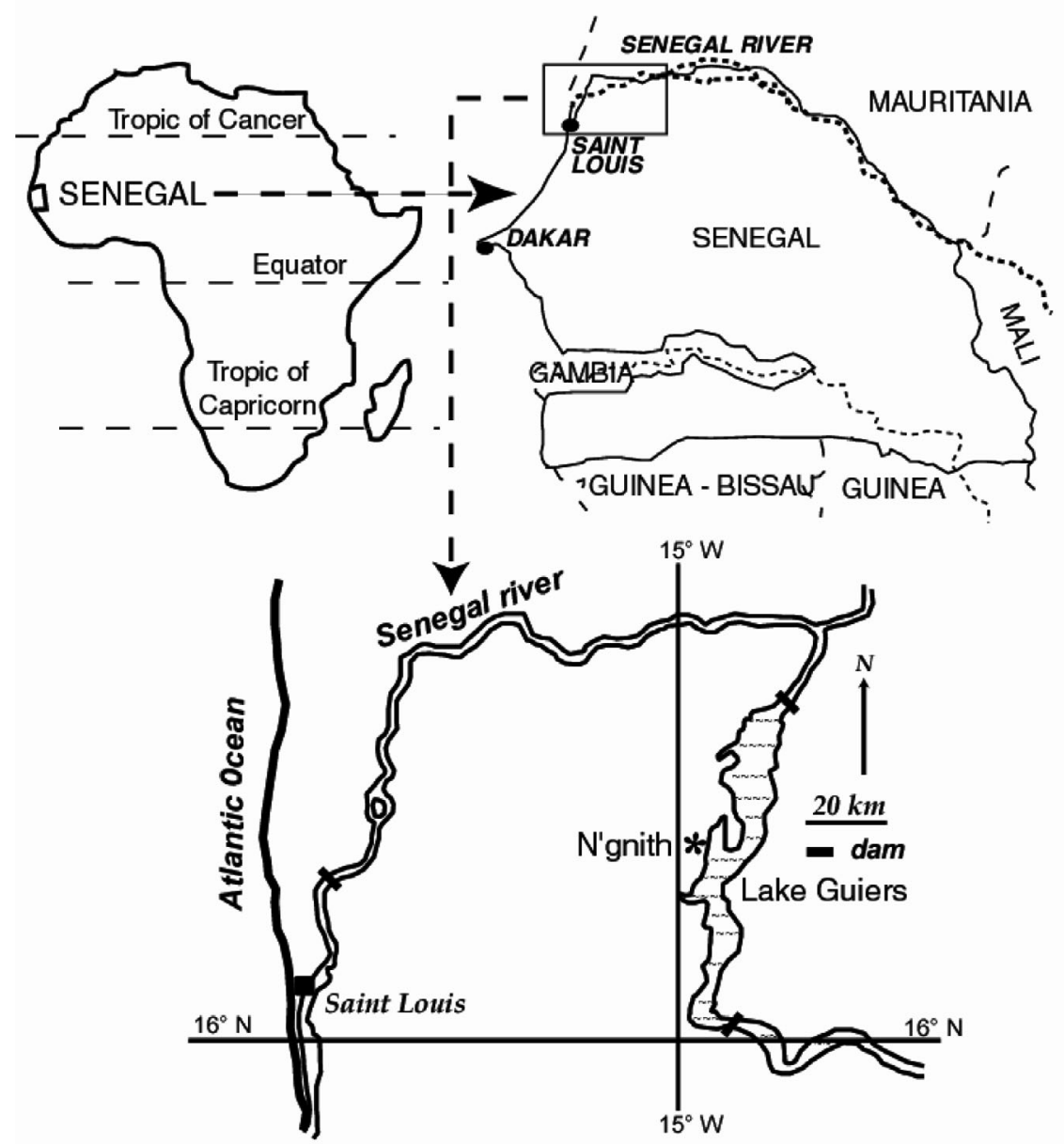

Fig. 1. Location of Lake Guiers, in the northern part of Senegal, close to the border with Mauritania. The sampling station $(\boldsymbol{*})$ is near the $\mathrm{N}^{\prime}$ gnith pumping plant, $200 \mathrm{~m}$ away from the west bank of the central basin to be the main factor in biomass control, and we must be aware of possible limitations due to macro- and micro-nutrients. These limitations could involve scarce compounds that act as key co-factors for essential functions. For example, iron bioavailability, which is increased when the river floods, has recently been shown to trigger bloom formation by a heterocystous cyanobacterium in estuarine waters (Watkinson et al. 2005). The aim of the present study was to clarify the environmental conditions, particularly with regard to nutrients, that favor or restrict $C$. raciborskii growth in Lake Guiers, and also in other Sahelian lakes and reservoirs.

\section{MATERIALS AND METHODS}

Area studied. The local climate is Sahelian, with monthly average air temperatures ranging from 23 to $30^{\circ} \mathrm{C}$. Annual rainfall is about $250 \mathrm{~mm}$, most of which falls between June and September (Cogels 1984, Cogels et al. 2001, Arfi et al. 2003). With a surface area of $300 \mathrm{~km}^{2}$ (maximum length $50 \mathrm{~km}$ and maximum width 7 km; Fig. 1) and a mean depth of $2 \mathrm{~m}$, Lake Guiers is the largest freshwater resource of the country (Cogels 1984, Cogels et al. 2001). The lake is mainly fed from its northern end by the Senegal River, which overflows between July and November. The watershed of about $290000 \mathrm{~km}^{2}$ is arid, the soil environment mostly lateritic. The surrounding vegetation is rather sparse, with a typical savannah landscape. Environmental data used in this study were collected from March 2002 to March 2003 in the central part of the lake, near N'gnith (Fig. 1). They were taken from Arfi et al. (2003) and from R. Arfi, N. Ba, M. Bouvy, C. Corbin, S. Ka, M. Pagano \& S. Sané (pers. comm.). The yearly water temperature ranged between $19^{\circ} \mathrm{C}$ in February and $33^{\circ} \mathrm{C}$ in September and October, and was around $26^{\circ} \mathrm{C}$ during our fieldwork. Solar radiation does not vary much, the highest values occurring from March to May $\left(>6500 \mathrm{~W} \mathrm{~d}^{-1}\right)$, the lowest from November to February $\left(<5000 \mathrm{~W} \mathrm{~d}^{-1}\right)$, and intermediate values from June to October. It is almost always windy. North-east continental trade winds blow from December to April, whereas north-west marine trade winds, fre- 
quently alternating with southerly winds, blow from May to October/November. Secchi disk values vary little over the year, between $70 \mathrm{~cm}$ in July and $40 \mathrm{~cm}$ in September/October at the beginning and end of the Senegal flooding period, respectively. The phytoplankton biomass, which generally ranges from 5 to 50 $\mu \mathrm{g}$ chlorophyll $a \mathrm{l}^{-1}$, is alternately dominated by the diatom Fragilaria sp. and the cyanobacterium Cylindrospermopsis raciborskii (Arfi et al. 2003, Berger et al. 2006). Besides being used for traditional fishing and irrigation purposes, the lake water is also used for drinking water. The N'gnith pumping plant (Fig. 1) supplies one-third of the water consumed in Dakar, with a flow rate of $50000 \mathrm{~m}^{3} \mathrm{~d}^{-1}$.

Bioassays of Cylindrospermopsis raciborskii in lake water. Nutrient-addition bioassays were designed to identify which nutrients restrict or stimulate the development of C. raciborskii in the lake. Water was sampled

Table 1. List of ultra-pure chemicals and their main characteristics. Final concentrations of nutrients in enriched water

\begin{tabular}{|lrccr|}
\hline Chemical & $\begin{array}{c}\text { Purity } \\
(\%)\end{array}$ & $\begin{array}{c}\text { Sigma- } \\
\text { Aldrich ref. }\end{array}$ & Element & $\begin{array}{r}\text { Final } \\
\text { conc. }\end{array}$ \\
\hline $\mathrm{NH}_{4} \mathrm{Cl}$ & 99.998 & $25,413-4$ & $\mathrm{~N}$ & $250 \mu \mathrm{M}$ \\
$\mathrm{NaNO}_{3}$ & 99.995 & $22,993-8$ & $\mathrm{~N}$ & $250 \mu \mathrm{M}$ \\
$\mathrm{NaH}_{2} \mathrm{PO}_{4}$ & 99.999 & $22,990-3$ & $\mathrm{P}$ & $25 \mu \mathrm{M}$ \\
$\mathbf{E M ~ = ~ m i x t u r e ~ o f ~ o l i g o e l e m e n t s ~ a n d ~ E D T A ~}$ & & \\
$\mathrm{KHCO}_{3}$ & $>99.99$ & $43,158-3$ & $\mathrm{C}, \mathrm{K}$ & $25 \mu \mathrm{M}$ \\
$\mathrm{MgCl}_{2}, 6 \mathrm{H}_{2} \mathrm{O}$ & 99.995 & $25,577-7$ & $\mathrm{Mg}$ & $26 \mu \mathrm{M}$ \\
$\mathrm{CaCl}_{2}, 2 \mathrm{H}_{2} \mathrm{O}$ & 99.99 & $47,087-2$ & $\mathrm{Ca}$ & $25 \mu \mathrm{M}$ \\
$\mathrm{FeCl}_{2}, 4 \mathrm{H}_{2} \mathrm{O}$ & 99.995 & $38,002-4$ & $\mathrm{Fe}$ & $500 \mathrm{nM}$ \\
$\mathrm{H}_{3} \mathrm{BO}_{3}$ & 99.999 & $20,287-8$ & $\mathrm{~B}$ & $5 \mu \mathrm{M}$ \\
$\mathrm{MnCl}_{2}$ & 99.99 & $42,944-9$ & $\mathrm{Mn}$ & $900 \mathrm{nM}$ \\
$\mathrm{ZnCl}_{2}$ & 99.999 & $42,943-0$ & $\mathrm{Zn}$ & $400 \mathrm{nM}$ \\
$\left.\mathrm{Co}_{2} \mathrm{CH}_{3} \mathrm{CO}_{2}\right)_{4}, 4 \mathrm{H}_{2} \mathrm{O}$ & 99.999 & $43,787-5$ & $\mathrm{Co}$ & $10 \mathrm{nM}$ \\
$\mathrm{CuCl}_{2}, 2 \mathrm{H}_{2} \mathrm{O}$ & 99.999 & $45,909-7$ & $\mathrm{Cu}$ & $70 \mathrm{pM}$ \\
$\mathrm{Na}_{2} \mathrm{MoO}_{4}, 2 \mathrm{H}_{2} \mathrm{O}$ & $>99.99$ & $48,096-7$ & $\mathrm{Mo}$ & $250 \mathrm{nM}$ \\
$\mathrm{Na}_{2} \mathrm{SO}_{4}$ & $>99.99$ & $43,148-6$ & $\mathrm{~S}$ & $25 \mu \mathrm{M}$ \\
$\mathrm{EDTA}$ & 99.999 & $43,178-8$ & $\mathrm{EDTA}$ & $2.3 \mu \mathrm{M}$ \\
& & & & \\
\hline
\end{tabular}

Table 2. Concentrations of major and trace elements in the culture media used in the present study (ASM1/8) and in Lake Guiers water on 22 March 2003. NA: not available

\begin{tabular}{|lrrcrr|}
\hline Chemical & ASM1/8 & In situ & Chemical & ASM1/8 & In situ \\
\hline Acetate & $20 \mathrm{nM}$ & $\mathrm{NA}$ & EDTA $^{-}$ & $33 \mu \mathrm{M}$ & $\mathrm{NA}$ \\
$\mathrm{Co}$ & $10 \mathrm{nM}$ & $0.5 \mathrm{nM}$ & $\mathrm{HCO}_{3}{ }^{-}$ & $25 \mu \mathrm{M}$ & $1067 \mu \mathrm{M}$ \\
$\mathrm{Cu}$ & $70 \mathrm{pM}$ & $27 \mathrm{nM}$ & $\mathrm{H}_{4} \mathrm{SiO}_{4}$ & & $170 \mu \mathrm{M}$ \\
$\mathrm{Fe}$ & $500 \mathrm{nM}$ & $313 \mathrm{nM}$ & $\mathrm{K}^{+}$ & $25 \mu \mathrm{M}$ & $51 \mu \mathrm{M}$ \\
$\mathrm{Mo}$ & $250 \mathrm{nM}$ & $<0.5 \mathrm{nM}$ & $\mathrm{Mg}^{2+}$ & $26 \mu \mathrm{M}$ & $239 \mu \mathrm{M}$ \\
$\mathrm{Mn}$ & $900 \mathrm{nM}$ & $8 \mathrm{nM}$ & $\mathrm{Na}^{+}$ & $326 \mu \mathrm{M}$ & $1280 \mu \mathrm{M}$ \\
$\mathrm{Zn}$ & $400 \mathrm{nM}$ & $653 \mathrm{nM}$ & $\mathrm{NH}_{4}{ }^{+}$ & $250 \mu \mathrm{M}$ & $<1 \mu \mathrm{M}$ \\
$\mathrm{B}$ & $5 \mu \mathrm{M}$ & $<0.1 \mu \mathrm{M}$ & $\mathrm{NO}_{3}{ }^{-}$ & $250 \mu \mathrm{M}$ & $5.3 \mu \mathrm{M}$ \\
$\mathrm{Ca}$ & $25 \mu \mathrm{M}$ & $227 \mu \mathrm{M}$ & $\mathrm{PO}_{4}{ }^{3-}$ & $25 \mu \mathrm{M}$ & $0.1 \mu \mathrm{M}$ \\
$\mathrm{Cl}$ & $356 \mu \mathrm{M}$ & $1065 \mu \mathrm{M}$ & $\mathrm{SO}_{4}{ }^{2-}$ & $25 \mu \mathrm{M}$ & $63.2 \mu \mathrm{M}$ \\
\hline
\end{tabular}

in March and in April 2003 at the N'gnith water pumping plant (Fig. 1), from the tip of a $200 \mathrm{~m}$ long dike. It was cleared of its phytoplankton and inorganic particles by gentle filtration over a GF/C Whatman filter (nominal porosity $1.2 \mu \mathrm{m}$ ). The absence of residual phytoplankton cells from the lake was confirmed under the microscope, and filtered lake water was inoculated with C. raciborskii (Strain PMC 118.02 isolated from Lake Guiers). The inoculum cultures had been previously acclimatized for several weeks at $28^{\circ} \mathrm{C}$ under a 14:10 h light:dark cycle, with a PAR (photosynthetically active radiation) of $80 \mu \mathrm{mol}$ photons $\mathrm{m}^{-2} \mathrm{~s}^{-1}$, in 8-fold diluted ASM1 medium (Gorham et al. 1964). The chlorophyll a concentration of the C. raciborskii suspension was adjusted at the beginning of the experiment to match the concentration of chlorophyll $a$ in the lake at the time the water was sampled (18 to $36 \mu \mathrm{g} \mathrm{l}^{-1}$ ). Cyanobacterial suspensions in filtered lake water were then enriched with various different combinations of nutrients. The composition and final concentrations of the nutrient spikes were based on the cyanobacterial culture media ASM1 diluted 8-fold (Table 1). Possible unintended contamination by trace compounds was limited by using highpurity chemicals (Sigma-Aldrich, references in Table 1).

In a first experiment, Cylindrospermopsis raciborskii was grown in Erlenmeyer flasks filled with filtered lake water collected on 22 March 2003. The concentrations of major and trace elements in this water are indicated in Table 2. The water was enriched with each of the 3 following compounds and various combinations of them according to a $2^{3}$ full factorial design with 4 replications: (1) DIN (dissolved inorganic nitrogen: $\mathrm{NaNO}_{3}$ $\left.+\mathrm{NH}_{4} \mathrm{Cl}\right)$, (2) $\mathrm{P}\left(\mathrm{PO}_{4}\right)$ and (3) EM (EDTA plus a mixture of elements, including $\mathrm{S}, \mathrm{Fe}, \mathrm{B}, \mathrm{Ca}, \mathrm{Co}, \mathrm{Cu}, \mathrm{Mg}$, $\mathrm{Mn}, \mathrm{Mo}$ and $\mathrm{Zn}$ ). The Erlenmeyer flasks were gently shaken by hand twice a day, and were maintained under controlled conditions of temperature $\left(28^{\circ} \mathrm{C}\right)$ and light $(80 \mu \mathrm{mol}$ photons $\mathrm{m}^{-2} \mathrm{~s}^{-1}$ provided by daylight fluorescent tubes OSRAM Lumilux 'de luxe', with a 14:10 h light:dark photoperiod).

In a second experiment, Cylindrospermopsis raciborskii was grown in 13 sets of triplicate $60 \mathrm{ml}$ borosilicate 
test tubes filled with $50 \mathrm{ml}$ of GF/C filtered lake water sampled on 1 April 2003. The first set was enriched with complete, diluted ASM1 mixture and the second set with diluted ASM1 mixture without DIN. Each of the other 11 sets was enriched with diluted ASM1 without DIN and without 1 of the elements in the EM mixture: EDTA, $\mathrm{S}, \mathrm{Fe}, \mathrm{B}, \mathrm{Ca}, \mathrm{Co}, \mathrm{Cu}, \mathrm{Mg}, \mathrm{Mn}, \mathrm{Mo}$, or $\mathrm{Zn}$. The tubes were attached to a vertical rotating Plexiglas disc, partly immersed in circulating tap water (Leboulanger et al. 2006). The disc was rotated at 1 rpm under shaded $(20 \%)$ natural light. This device ensured that all the tubes were subjected to identical conditions of shaking, temperature $\left(25\right.$ to $\left.30^{\circ} \mathrm{C}\right)$ and irradiance.

The incubations lasted from 6 to $10 \mathrm{~d}$, which was long enough for the effects of the nutrient additions on biomass to reach their peak. The cyanobacterial biomass was assessed daily from its in vivo fluorescence (IVF), according to Leboulanger et al. (2006). The IVF was measured using a Turner Designs TD 700 fluorometer through a $436 / 680 \mathrm{~nm}\left(\mathrm{l}_{\mathrm{ex}} / \mathrm{l}_{\mathrm{em}}\right)$ filter kit. Cell counts, and biomass and heterocyst density estimations were carried out on fixed sample (Lugol's iodine), under a Nikon-Optiphot-2 microscope in a $1 \mu \mathrm{l} \mathrm{Mal-}$ assez cell. Cylindrospermopsis raciborskii biomass values are expressed as the number of $100 \mu \mathrm{m}$ long trichomes $\mathrm{ml}^{-1}$.

Chemical analysis. Field analysis: Temperature and $\mathrm{pH}$ were measured in situ, and several liters of water samples were collected in acid-cleaned, high-density polyethylene bottles for analysis and incubation experiments.

Analyses performed at the 'field' laboratory: Alkalinity analysis: The alkalinity, as defined by Stumm \& Morgan (1981), was analyzed following the spectrophotometric method described by Podda \& Michard (1994) and Sarazin et al. (1999). Since the water samples being analyzed contained very low concentrations of reduced nitrogen $\left(\mathrm{NH}_{4}^{+}\right)$and phosphate, the species taken into account in the water alkalinity, i.e. the concentrations of $\mathrm{NH}_{3}$ and $\mathrm{HPO}_{4}{ }^{2-}$ can be neglected. The dissolved silica concentration in Lake Guiers is always close to $170 \mu \mathrm{M}$. This means that the ionized fraction of $\mathrm{H}_{3} \mathrm{SiO}_{4}^{-}$at the observed maximum $\mathrm{pH}$ values $\left(\mathrm{pH}_{\max }=\right.$ 8.72 ) is negligible relative to the carbonate alkalinity; thus, the measured alkalinity can be reduced to the following expression: $\mathrm{Alk}=\left[\mathrm{HCO}_{3}{ }^{-}\right]+2\left[\mathrm{CO}_{3}{ }^{2-}\right]$, since both $\left[\mathrm{H}^{+}\right]$and $\left[\mathrm{OH}^{-}\right]$can be ignored.

Carbon analysis: The total dissolved inorganic carbon (DIC) was calculated from the measured values of alkalinity and $\mathrm{pH}$.

Phosphate analysis: The dissolved inorganic phosphorus (DIP) was determined by the standard molybdenumblue method, using a Merck-Spectroquant PMB kit. The absorbance was measured at $880 \mathrm{~nm}$ in $50 \mathrm{~mm}$ cells.
Ammonium analysis: Ammonium was determined using the Merck-Spectroquant analysis kit, which is a modified method of the Berthelot's reaction. The absorbance of indothymol blue was measured at $690 \mathrm{~nm}$ in $10 \mathrm{~mm}$ optical cells.

Analyses performed at the Paris laboratory: Major anion analysis: $\mathrm{Cl}^{-}, \mathrm{NO}_{3}{ }^{-}$and $\mathrm{SO}_{4}{ }^{2-}$ were determined by HPLC (high-performance liquid chromatography) using a Dionex 2000i chromatograph. Ion separation was performed using an AS14 column, and detection was carried out by conductimetry.

Major cation analysis: The total $\mathrm{Na}^{+}, \mathrm{K}^{+}, \mathrm{Ca}^{2+}$ and $\mathrm{Mg}^{2+}$ contents were measured either by flameless atomic absorption spectrophotometry (FAAS) on a Solar M6 spectrophotometer (Thermo-Optek) or by ICP-AES (inductively coupled plasma-atomic emission spectrometry, Perkin-Elmer Optima 3000).

Minor element analysis: Total Mn and Fe determinations were performed by FAAS on a Solar M6 spectrophotometer. Trace elements ( $\mathrm{B}, \mathrm{Co}, \mathrm{Cu}, \mathrm{Zn}$ and $\mathrm{Mo}$ ) were analyzed by ICP-MS (inductively coupled plasma-mass spectrometry, Thermo-Optek-Fisons VG elemental).

Since all samples collected in the field and during incubation experiments were filtered on $0.22 \mu \mathrm{m}$ Millex GV, blank samples were obtained by filtering $50 \mathrm{ml}$ of Milli-Q water over the same type of filter. Indium and the SLRS international standard were used as the internal and external standards, respectively.

Calculation of the chemical composition: The chemical composition of the culture medium was determined using the MINEQL+ calculation code: this computer program (Scbecher \& McAvoy 1991) calculates the composition of any aqueous solution under chemical equilibrium conditions and at a given temperature. Input variables are the total concentrations, $\mathrm{pH}$, alkalinity or DIC, or $\mathrm{CO}_{2}$ partial pressure. Our data allowed us to use the $\mathrm{pH}$ and alkalinity as input variables. Since iron is the only element that is expected to generate a solid phase [iron hydroxide $\left.\mathrm{Fe}(\mathrm{OH})_{3}\right]$, the 2 following conditions can be imposed on the system. (1) Iron hydroxide is not expected to determine the solubility of Fe(III). The program therefore yields a value of the saturation index with respect to the solid phase under consideration (i.e. the solution can be oversaturated, at equilibrium, or undersaturated). We have chosen the least insoluble iron hydroxide (ferrihydrite), which is also the most likely phase to precipitate as an authigenic mineral under natural conditions within the lake. (2) Iron hydroxide is assumed to be in equilibrium with the solution at a given $\mathrm{pH}$ : the program therefore sets the saturation index to 1 with respect to ferrihydrite and calculates the amount of solid precipitated. The concentrations of dissolved iron species are then calculated taking this condition into account. 
After checking that the water was always oversaturated with $\mathrm{Fe}$ (III) hydroxides, we chose the second hypothesis, since for $\mathrm{pH}$ values ranging from 7.5 to 8.5 , Fe-hydroxide is rapidly precipitated when oversaturation prevails (Sigg et al. 1992). This hypothesis, i.e. equilibrium with ferrihydrite, was then used for all further calculations concerning the chemical speciation in the solutions.

\section{RESULTS}

\section{Bioassays with Cylindrospermopsis raciborskii in lake water}

In the first experiment, daily measurements of IVF during $10 \mathrm{~d}$ of incubation showed that cultures enriched with $\mathrm{PO}_{4}{ }^{3-}$ alone did not differ from the control (the control [C] and $\mathrm{PO}_{4}{ }^{3-}$ enriched samples [P] are superimposed in Fig. 2). A significant increase in IVF was observed in assays spiked with DIN without EDTA plus the trace element mixture EM (DIN and DIN + P, t-test, $\mathrm{p}<0.05)$. Up to Day 5, a similar increase in IVF was noticed in the EM enrichment assays, and this increase was even greater from Day 5 . From the beginning to Day 4, the greatest increase in IVF was measured in assays in which DIN + EM had been added simultaneously (assays DIN + EM and DIN + P + EM). After $5 \mathrm{~d}$ of incubation, adding $\mathrm{PO}_{4}{ }^{3-}$ had a synergistic

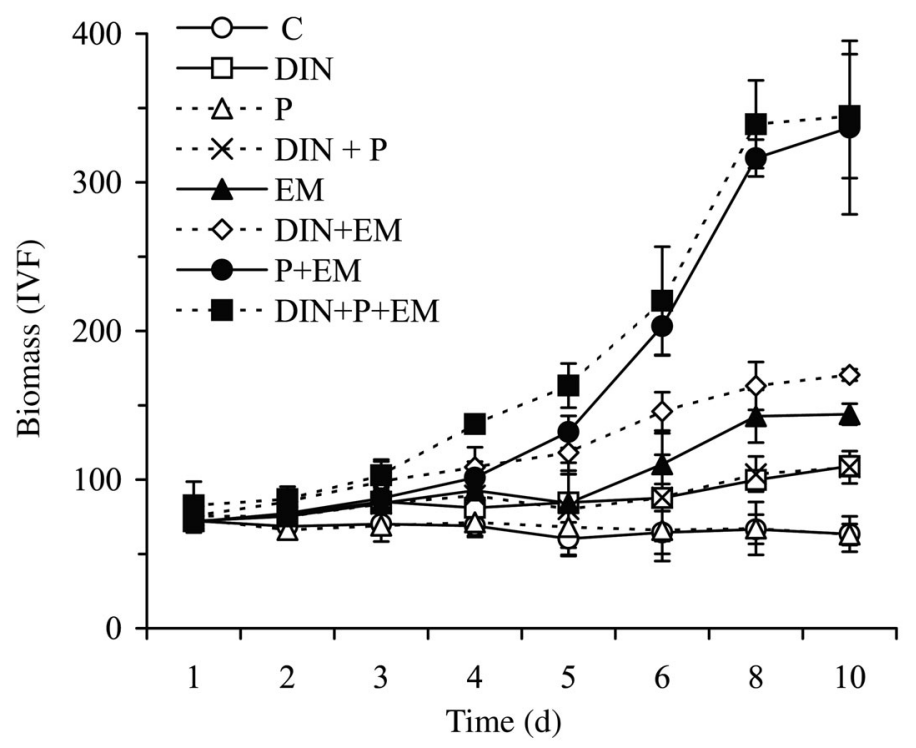

Fig. 2. Cylindrospermopsis raciborskii. Growth in filtered Lake Guiers water enriched by different combinations of nutrients, expressed as the in vivo fluorescence of chlorophyll a (IVF). Means of 4 batch cultures $( \pm$ SD). C: control culture without nutrient addition; DIN: dissolved inorganic nitrogen; $\mathrm{P}: \mathrm{PO}_{4}{ }^{3-}$ enriched samples; EM: EDTA plus a mixture of elements, including $\mathrm{S}, \mathrm{Fe}, \mathrm{B}, \mathrm{Ca}, \mathrm{Co}, \mathrm{Cu}, \mathrm{Mg}, \mathrm{Mn}, \mathrm{Mo}$ and $\mathrm{Zn}$

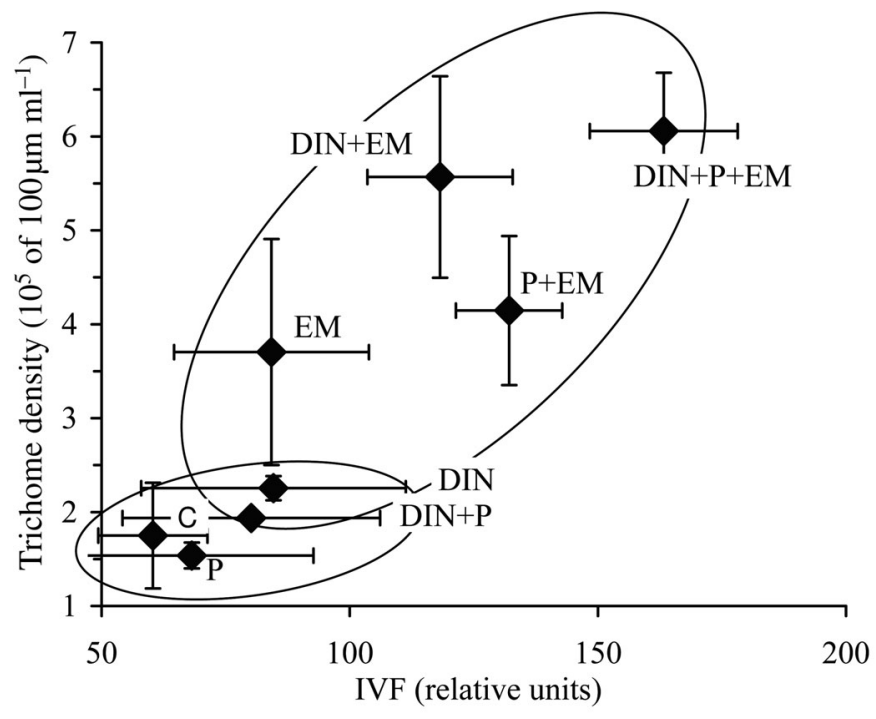

Fig. 3. Cylindrospermopsis raciborskii. Relationship between the in vivo fluorescence of chlorophyll a (IVF) and trichome abundance (no. of $100 \mu \mathrm{m}$ long trichomes $\mathrm{ml}^{-1}$ ) after $5 \mathrm{~d}$ of growth in filtered Lake Guiers water enriched by different combinations of nutrients. Each data point is the mean of 4 batch cultures $( \pm \mathrm{SD})$

effect with the EM enrichment $(P+E M)$, and adding DIN no longer enhanced growth (assays DIN + P + $\mathrm{EM}=$ assays $\mathrm{P}+\mathrm{EM})$.

These bioassays suggest that there is a primary limitation to Cylindrospermopsis raciborskii growth in filtered water from Lake Guiers due to the limited availability of nitrogen. However, one or more elements present in the EM mixture produced effects similar to those of adding DIN. This mixture was, in fact, even more effective than DIN after incubating for $5 \mathrm{~d}$ (Fig. 2, assay $\mathrm{P}+\mathrm{EM}>\mathrm{DIN}+\mathrm{EM}$ ). Fig. 3 confirms that the positive impact of EM on IVF was indeed linked to the abundance of $C$. raciborskii, and not to an undesirable contaminant alga or to any increase in fluorescence yield or cellular chlorophyll a content. The addition of EM without DIN was also associated with a significantly higher ( $p=0.01$, chi-squared test) proportion of heterocystous trichomes than was obtained without EM (Fig. 4). In contrast, there was no significant difference between the bioassays without DIN and EM and the bioassays with DIN but without EM (chi-squared test). We can therefore infer that one or more components of the EM mixture must have been promoting the growth of $C$. raciborskii and the differentiation of heterocysts.

The average IVF values from the second experiment of each triplicate set during the $6 \mathrm{~d}$ incubation period are reported in Fig. 5. The greatest growth of Cylindrospermopsis raciborskii was obtained when the lake water had been enriched with diluted complete ASM1 medium. A lack of DIN (ASM1/8 - DIN) reduced the 


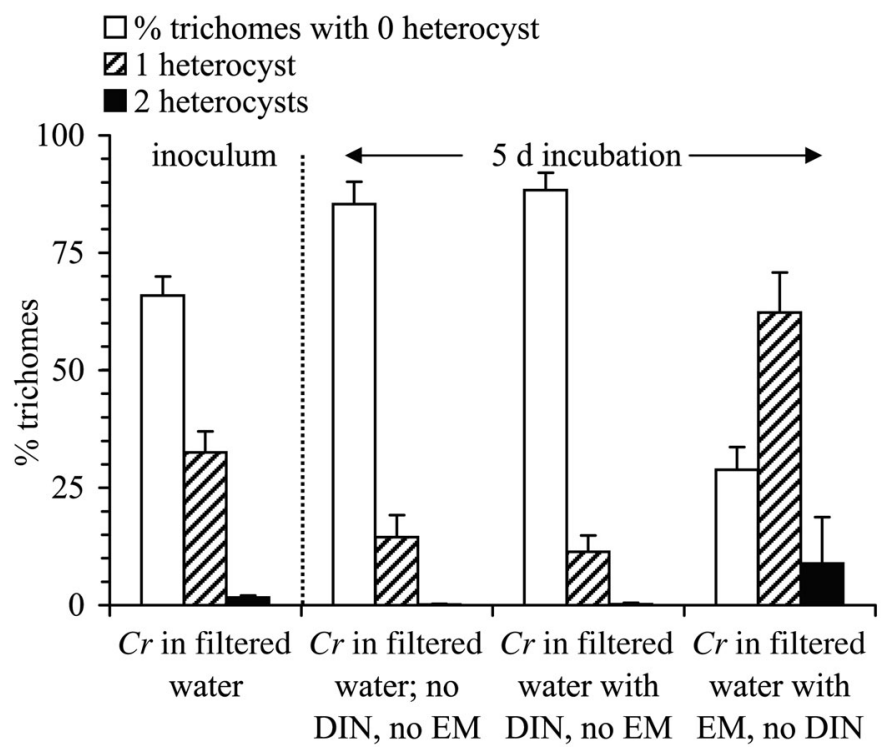

Enrichment conditions

Fig. 4. Cylindrospermopsis raciborskii. Percentage of trichomes with 0,1 , or 2 heterocysts at the beginning of the experiment (inoculum), and after $5 \mathrm{~d}$ of growth, according to the nutrient enrichment. Means of 5 batch cultures $( \pm \mathrm{SD})$

rate of growth by a factor of 2 . This set could not be distinguished from the other sets in which, in addition to DIN, some other component was also missing, except for the set in which both EDTA and DIN were missing, where IVF was lower.

This second series of bioassays confirmed that $\mathrm{N}$ is the main factor limiting the growth of Cylindrospermopsis raciborskii in filtered water from Lake Guiers. The data also show that all the components of the EM mix were present in the lake water at concentrations high enough to sustain the growth of the cyanobacterium, since growth was possible even when they were not added, except in the case of EDTA. The strain only failed to grow when neither EDTA nor DIN had been supplemented. We can infer that it is only the presence of EDTA, a strongly chelating molecule, that is able to offset the lack of DIN and allows the cyanobacterium to keep on growing.

\section{Chemical composition (dissolved forms) of the culture medium}

The role of EDTA in the medium can be deduced if the different concentrations and speciation of the major and trace elements are known when EDTA is added and when it is not. This was calculated by running the MINEQL+ computer program using the inputs summarized in Table 2.
During the bioassay experiments, $\mathrm{pH}$ values ranged between 7.5 and 8.5 , depending on the photosynthetic activity of the phytoplankton. MINEQL+ calculations were run with these 2 extreme $\mathrm{pH}$ values. On the basis of these inputs, Table 3 shows calculated concentrations of the free ions of trace elements. These cations, according to the Free Ion Model, are those most subjected to biological uptake (Sunda 1989). Their concentration may change by several orders of magnitude depending on the $\mathrm{pH}$ range and whether EDTA has been added to the culture medium.

$\mathrm{Fe}^{3+}$ was the free ion that exhibited by far the lowest calculated concentrations $\left(8 \times 10^{-20}\right.$ to $8 \times 10^{-23} \mathrm{M}$ at $\mathrm{pH} 7.5$ and 8.5, respectively) in ASM1-enriched water from Lake Guiers. Nevertheless, bioassay results showed that growth without $\mathrm{FeCl}_{3}$ and DIN in ASM1-enriched water (assay ASM1/8 - DIN - Fe, open circles in Fig. 5, was the same as that when only DIN had been eliminated (assay ASM1/8 - DIN, shaded diamonds in Fig. 5). This suggests that enriching the lake water with $\mathrm{FeCl}_{3}$ without simultaneously enriching it with DIN did not allow Cylindrospermopsis raciborskii to grow. Moreover, eliminating DIN and EDTA from the ASM1 enrichment, even if $\mathrm{FeCl}_{3}$ was maintained (assay ASM1/8 - DIN - EDTA, the black squares in Fig. 5) stopped the growth of the

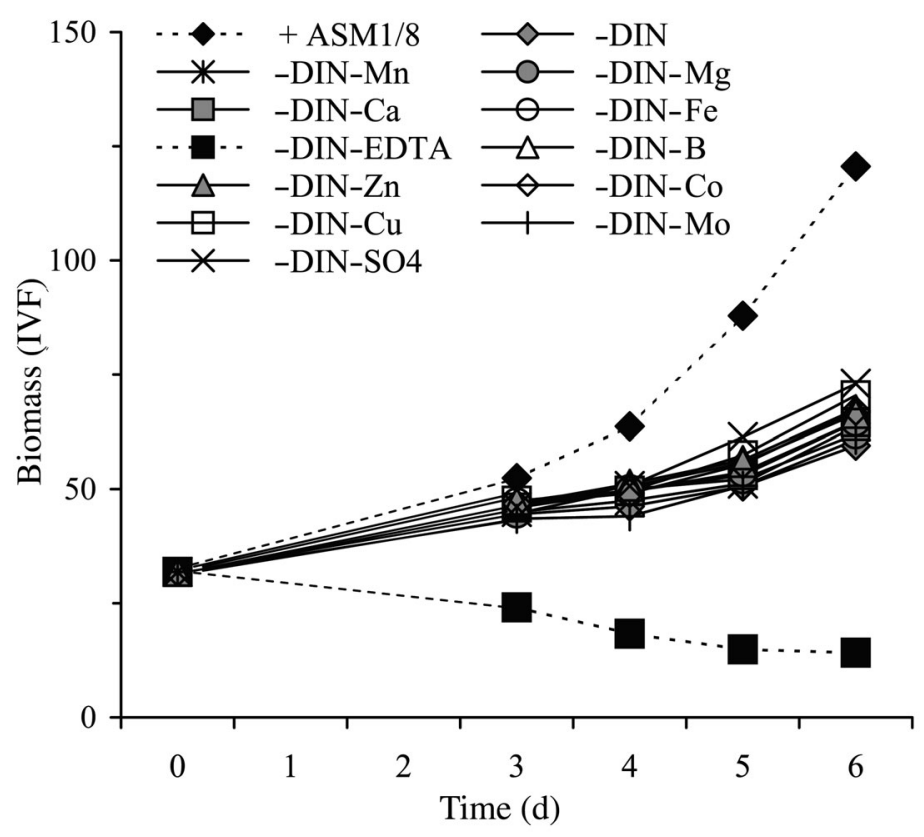

Fig. 5. Cylindrospermopsis raciborskii. IVF values showing the variations in the growth of C. raciborskii cultured in filtered Lake Guiers water enriched by complete ASM1 medium $(\bullet)$ or by ASM1 without DIN and without 1 of the components of the mixture EDTA + trace elements. Mean in vivo fluorescence of chlorophyll a (IVF) of triplicate samples 
Table 3. Concentrations $\left(\mathrm{mol} \mathrm{l}^{-1}\right.$ ) of simple cationic forms in Lake Guiers water, enriched by ASM1/8, calculated by MINEQL+. Equilibrium is assumed with ferrihydrite at $\mathrm{pH} 7.5$ or 8.5 and EDTA at 0 or $2.33 \mu \mathrm{M}$

\begin{tabular}{|lcccc|}
\hline \multirow{2}{*}{ Cation } & \multicolumn{2}{c}{ pH 8.5} & \multicolumn{2}{c|}{ pH 7.5} \\
& $\begin{array}{c}\text { Without } \\
\text { EDTA }\end{array}$ & With & Without & With \\
& & & EDTA & EDTA \\
\hline $\mathrm{Ca}^{2+}$ & $2.39 \times 10^{-4}$ & $2.38 \times 10^{-4}$ & $2.44 \times 10^{-4}$ & $2.44 \times 10^{-4}$ \\
$\mathrm{Co}^{2+}$ & $8.15 \times 10^{-9}$ & $8.53 \times 10^{-12}$ & $9.85 \times 10^{-9}$ & $1.22 \times 10^{-11}$ \\
$\mathrm{Cu}^{2+}$ & $3.17 \times 10^{-10}$ & $9.97 \times 10^{-14}$ & $2.99 \times 10^{-9}$ & $1.44 \times 10^{-13}$ \\
$\mathrm{Fe}^{3+}$ & $8.01 \times 10^{-23}$ & $8.01 \times 10^{-23}$ & $8.02 \times 10^{-20}$ & $8.02 \times 10^{-20}$ \\
$\mathrm{~K}^{+}$ & $7.60 \times 10^{-5}$ & $7.60 \times 10^{-5}$ & $7.60 \times 10^{-5}$ & $7.63 \times 10^{-5}$ \\
$\mathrm{Mg}^{2+}$ & $2.56 \times 10^{-4}$ & $2.56 \times 10^{-4}$ & $2.59 \times 10^{-4}$ & $2.59 \times 10^{-4}$ \\
$\mathrm{Mn}^{2+}$ & $8.59 \times 10^{-7}$ & $1.97 \times 10^{-7}$ & $8.64 \times 10^{-7}$ & $2.61 \times 10^{-7}$ \\
$\mathrm{Zn}^{2+}$ & $5.01 \times 10^{-7}$ & $1.21 \times 10^{-9}$ & $9.28 \times 10^{-7}$ & $1.77 \times 10^{-9}$ \\
\hline
\end{tabular}

Table 4. Output simulations by MINEQL+ of Fe(III) species concentrations $\left(\mathrm{mol} \mathrm{l}^{-1}\right)$ in Lake Guiers water, enriched by ASM1/8, for $\mathrm{pH} 7.5$ and 8.5, with or without EDTA

\begin{tabular}{|c|c|c|c|c|}
\hline \multirow[b]{2}{*}{ Fe species } & \multicolumn{2}{|c|}{ pH 8.5} & \multicolumn{2}{|c|}{ pH 7.5} \\
\hline & $\begin{array}{l}\text { Without } \\
\text { EDTA }\end{array}$ & $\begin{array}{c}\text { With } \\
\text { EDTA }\end{array}$ & $\begin{array}{l}\text { Without } \\
\text { EDTA }\end{array}$ & $\begin{array}{c}\text { With } \\
\text { EDTA }\end{array}$ \\
\hline $\mathrm{Fe}^{3+}$ & $8.01 \times 10^{-23}$ & $8.01 \times 10^{-23}$ & $8.02 \times 10^{-20}$ & $8.02 \times 10^{-20}$ \\
\hline $\mathrm{Fe}$ [EDTA] & & $2.10 \times 10^{-10}$ & & $1.44 \times 10^{-7}$ \\
\hline $\mathrm{FeOH}$ [EDTA] & & $1.30 \times 10^{-9}$ & & $8.90 \times 10^{-8}$ \\
\hline $\mathrm{Fe}(\mathrm{OH})_{2}[\mathrm{EDTA}]$ & & $5.09 \times 10^{-11}$ & & $3.48 \times 10^{-10}$ \\
\hline $\mathrm{Fe}(\mathrm{OH})_{2}{ }^{+}$ & $1.21 \times 10^{-10}$ & $1.21 \times 10^{-10}$ & $1.21 \times 10^{-9}$ & $1.21 \times 10^{-9}$ \\
\hline $\mathrm{Fe}(\mathrm{OH})_{3}$ aq & $4.45 \times 10^{-10}$ & $4.45 \times 10^{-10}$ & $4.45 \times 10^{-10}$ & $4.45 \times 10^{-10}$ \\
\hline $\mathrm{Fe}(\mathrm{OH})_{4}^{-}$ & $1.23 \times 10^{-10}$ & $1.23 \times 10^{-10}$ & $1.23 \times 10^{-11}$ & $1.23 \times 10^{-11}$ \\
\hline Total soluble Fe(III) & $6.89 \times 10^{-10}$ & $2.25 \times 10^{-9}$ & $1.67 \times 10^{-9}$ & $2.35 \times 10^{-7}$ \\
\hline Ferrihydrite & $8.12 \times 10^{-7}$ & $8.11 \times 10^{-7}$ & $8.11 \times 10^{-7}$ & $5.79 \times 10^{-7}$ \\
\hline \% soluble Fe(III) & 0.1 & 0.3 & 0.2 & 28.8 \\
\hline
\end{tabular}

medium dramatically increased the concentration of total Fe(III), especially the soluble and potentially bioavailable species. At pH 7.5, it was increased by $>2$ orders of magnitude (from 1.67 to $235 \mathrm{nM}$ ). In vitro, these bioavailable species are currently denoted by Fe' (de Baar \& La Roche 2003, Parekh et al. 2004), and correspond to $\mathrm{Fe}^{3+}$ and $\mathrm{Fe}(\mathrm{OH})_{\mathrm{n}}{ }^{3-\mathrm{n}}$ plus $\mathrm{Fe}$ EDTA complexes.

Free ions of other trace metals $\left(\mathrm{Co}^{2+}\right.$, $\mathrm{Cu}^{2+}, \mathrm{Mn}^{2+}$ and $\mathrm{Zn}^{2+}$ ) are not controlled by an insoluble solid phase, and so their free ion concentration dropped when EDTA was added, because the metal-EDTA complexed forms increased. When no EDTA was supplied, the concentrations of free ions only changed with $\mathrm{pH}$, if the hydroxy-complexes were stable. According to the MINEQL+ outputs, concentrations of other complexes (i.e. chloride complexes) were quite negligible. Consequently, we were able to confirm that the free dissolved copper in the form of $\mathrm{Cu}^{2+}$, which we found to be the most toxic element for phytoplankton in our culture media, reached a concentration of $3 \times 10^{-9} \mathrm{M}$ in the absence of EDTA (Table 3). Such concentrations could be toxic for the phytoplankton, depending on the algal species present and environmen-

cyanobacteria, whereas when EDTA was not excluded from the ASM1 enrichment, population development was possible, even without DIN or Fe enrichment. This implies that EDTA and Fe had a positive effect and no effect, respectively, on the limitation of $C$. raciborskii growth by DIN. If we assume that ferrihydrite was at equilibrium, then the $\mathrm{Fe}^{3+}$ concentration is given by:

$$
\left[\mathrm{Fe}^{3+}\right]=\frac{K_{\mathrm{s}}}{K_{\mathrm{e}}^{3}}\left[\mathrm{H}^{+}\right]^{3}
$$

where $K_{\mathrm{s}}$ is the solubility product of ferrihydrite and $K_{\mathrm{e}}$ the dissociation constant of water. This means that when the $\mathrm{pH}$ changes by $<1$ unit, the $\mathrm{Fe}^{3+}$ concentration changes by $\leq 3$ orders of magnitude. The presence of EDTA does not affect the concentration of $\mathrm{Fe}^{3+}$, because EDTA does not control the solid-solution equilibrium. EDTA will only affect the concentrations of Fe-EDTA complexes and, in this way, indirectly increases the bioavailability of iron. It is furthermore obvious from Table 4 that adding EDTA to the culture tal features (Brand et al. 1986, Seidl et al. 1998). When EDTA was added, the free dissolved $\mathrm{Cu}^{2+}$ concentration dropped by 4 orders of magnitude (Table 3 ).

\section{DISCUSSION}

\section{Comments on the experimental protocol}

The advantages and limitations of bioassays and those of our experimental protocol are discussed in Dufour \& Berland (1999) and Leboulanger et al. (2006). The choice of the concentrations of nutrients added in these assays depends on conflicting needs. (1) The nutrients supplied as enrichments have to be present at significantly higher concentrations than those present in situ in order to differentiate clearly between the effect of the added nutrient and that of the native nutrient, and to generate a quick and significant response. However, (2) the concentrations of nutrients added should be as low as possible in order to prevent any 
modification of the assimilation mechanisms or the induction of toxic effects associated with excessive concentrations. Our choice was a compromise: 6 elements were added at concentrations higher than those found in situ (Co, Mo, Mn, B, N and P), whereas the other 9 were added at concentrations lower than those present in situ $(\mathrm{Cu}, \mathrm{Zn}, \mathrm{Ca}, \mathrm{Cl}, \mathrm{C}, \mathrm{K}, \mathrm{Mg}, \mathrm{Na}, \mathrm{S}$; Table 2). We maintained the relative proportions of elements in the ASM1 medium (ASM1 medium diluted 8-fold) that had been shown to be suitable for cyanobacterial culture. Moreover, the concentration of Fe added, an element of interest for our purposes, was quite close to the concentration present in situ.

Bioassays in Erlenmeyer flasks (first experiment) were carried out at $28^{\circ} \mathrm{C}$ and $80 \mu \mathrm{mol}$ photons $\mathrm{m}^{-2} \mathrm{~s}^{-1}$, which, according to Briand et al. (2004), are the optimum temperature and light conditions, respectively, for the growth of Cylindrospermopsis raciborskii Guiers strains. In the second experiment, test tubes were incubated under shaded (20\%), natural light, i.e. at $\leq 400 \mu \mathrm{mol}$ photons $\mathrm{m}^{-2} \mathrm{~s}^{-1}$, a light intensity easily tolerated by $C$. raciborskii Guiers strains, without photoinhibition (Briand et al. 2004). Tap water was circulated to keep the temperature between 25 and $30^{\circ} \mathrm{C}$.

\section{What role can EDTA be expected to play?}

The role of EDTA can be summarized by answering the following: Is EDTA a nitrogen source in itself (it contains $2 \mathrm{~N}$ atoms molecule $\mathrm{e}^{-1}$ ), or is it a chelator, the presence of which modifies the bioavailability of 1 or several of the trace metals present in the culture medium?

The presence of EDTA at a concentration of $2.33 \mu \mathrm{M}$ increases the total $\mathrm{N}$ concentration by $4.6 \mu \mathrm{M}$. This corresponds to $<1 \%$ of the DIN from other sources in the culture medium (Table 2). Moreover, the biodegradability of this molecule is assumed to be low (Jung et al. 2004), which suggests that this compound is unlikely to be used as a nutrient source. We can therefore expect that the responses observed are linked to the chelating function of EDTA towards transition metals. EDTA can act as a chelator with regard to an excess of a potentially toxic metal, or it can increase the bioavailability of elements that are essential for biological functions. We cannot exclude the possibility that EDTA could have a detoxifying effect on $\mathrm{Cu}^{2+}$. The addition of EDTA did indeed cause a drastic fall in the concentration of $\mathrm{Cu}^{2+}$ (see above and Table 3), which should have abolished any toxic effects of this metal.

$\mathrm{Fe}^{3+}$ is clearly the free ion that displayed the lowest concentration in our culture media $\left(10^{-20}\right.$ to $10^{-23} \mathrm{M}$; Table 3). Such negligible concentrations could limit the uptake of Fe into the cell. It is well known that Fe is necessary for the biosynthesis and activity of many of the coenzymes that are essential to maintain vital functions (such as respiration, photosynthesis and nitrogen fixation; Morel \& Price 2003). However, bioassay results show clearly that adding EDTA can act as a substitute for adding DIN with regard to the development of Cylindrospermopsis raciborskii (Fig. 5). We can therefore infer that EDTA, by increasing the pool of soluble iron (Table 4), allows the C. raciborskii cells to initiate the biosynthesis of the coenzyme required for $\mathrm{N}_{2}$ fixation, i.e. nitrogenase. This induction of diazotrophy is confirmed by the dominance of heterocystous trichomes when EM was added without DIN, and by the low percentage of heterocystous trichomes in bioassays without EM and with or without DIN (Fig. 4). Diazotrophy is a strategy commonly used by heterocystous cyanobacteria to outcompete other phytoplanktonic species when nitrogen is limited in the environment (e.g. Fogg 1974, Spröber et al. 2003).

\section{Competition between cyanobacteria and bacteria for DIN assimilation and $\mathrm{N}_{2}$ fixation}

Bioassays with pure cultures of Cylindrospermopsis raciborskii in filtered lake water (Fig. 2) showed that adding DIN and EM separately induced cyanobacterial growth. From Day 6, in all bioassays, growth was greater in cultures with added EM than in those without EM. It can be seen that adding EM was more effective than adding DIN (EM $>$ DIN and $\mathrm{P}+\mathrm{EM}>\mathrm{P}+\mathrm{DIN})$ in promoting durable cell multiplication. As our cultures were not axenic and GF/C filtration of the lake water did not remove all the bacteria present, we can infer that competition would have occurred between bacteria and the cyanobacteria for nutrients. It is well known that $\mathrm{NH}_{4}{ }^{+}$is better assimilated by bacteria than by algae (e.g. Wheeler \& Kirchman 1986, Kirchman 2000). Moreover, high concentrations of dissolved organic carbon relative to the concentration of dissolved organic nitrogen were measured at N'gnith, our sampling site (1380 and $26 \mu \mathrm{mol} \mathrm{l^{-1 }}$, respectively, on $28 \mathrm{March} 1270$ and $27 \mu \mathrm{mol} \mathrm{l^{-1 }}$ on $31 \mathrm{March} 1000$ and

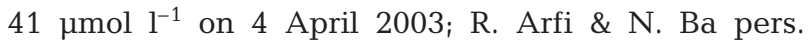
comm.). In water with such a deficiency of dissolved organic nitrogen, bacteria may be responsible for some, if not most, of the uptake and disappearance of $\mathrm{NO}_{3}^{-}$observed (Kirchman et al. 1991). Adding DIN could also lead to competition between bacteria and $C$. raciborskii for DIN assimilation. Such competition with bacteria for DIN and $\mathrm{N}_{2}$ assimilation by the heterocystic cyanobacterium $C$. raciborskii could explain why we found that adding EM was more effective than adding DIN alone (Fig. 2). 


\section{Nitrogenase activity could account for the annual cycle of Cylindrospermopsis raciborskii}

Can these laboratory experiments help us to understand the Cylindrospermopsis raciborskii blooms that occur in Lake Guiers? From 22 March to 1 April 2003, we noticed that $C$. raciborskii was present, but not dominant within the phytoplankton community. For example, on 29 March, the phytoplankton community consisted mainly of diatoms (about $3 \times 10^{4} \mathrm{cells} \mathrm{m}^{-1}$,

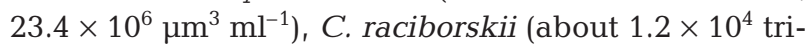
chomes $\mathrm{ml}^{-1}, 10.8 \times 10^{6} \mathrm{\mu m}^{3} \mathrm{ml}^{-1}$ ) and other filamentous cyanobacteria, dominated by Planktolyngbia species (about $0.6 \times 10^{4}$ filaments $\mathrm{ml}^{-1}, 1.5 \times 10^{6} \mathrm{\mu m}^{3} \mathrm{ml}^{-1}$ ). During this period, DIN concentrations were found to range between 0.7 and $4.4 \mu \mathrm{M}$ (data not shown), and so no DIN limitation of phytoplankton growth was expected. Under such in situ conditions, diazotrophy should not give C. raciborskii any competitive advantage over non-diazotrophic algae. During this period, we were able to induce a relative in vitro depletion of DIN by adding all the other nutrients but not DIN (Figs. $2 \& 5)$. Under such in vitro conditions, we observed $C$. raciborskii growth, despite this relative depletion of DIN, after inducing diazotrophy by adding EDTA (Figs. $2 \& 5$ ). Since our cultures were carried out in vitro, in filtered lake water, and at constant light and temperature, we cannot make any inference about the possible control of C. raciborskii biomass in situ by physical conditions, algal competitors, allosteric inhibition, or zooplankton grazing. We can only note that both DIN depletion, when it occurs, and diazotrophy could account for the dominance of $C$. raciborskii.

Periodic episodes of Cylindrospermopsis raciborskii dominance in Lake Guiers, with cell numbers and biovolumes corresponding to up to $40 \%$ of the phytoplankton (Arfi et al. 2003), generally occur between August and October, at the end of the flood period. During this period north-west winds predominate. As the lake is oriented from north-east to south-west, these winds should generate lower fetch, and therefore a higher water column vertical stability, than the north-east winds that blow from December to April. It has been suggested that this stability could favor cyanobacteria (Paerl 1988), including C. raciborskii (Padisak 1997) and this species particularly in Lake Guiers (Berger et al. 2006). However, winds blow nearly permanently, and are strong enough to mix the lake water column which is, on average, only $2 \mathrm{~m}$ deep. A diurnal thermal gradient of up to $2^{\circ} \mathrm{C}$ may develop in the middle of the day, but disappears every night (Sané 2006). Water temperature which peaks at around $30^{\circ} \mathrm{C}$ from August to November (Arfi et al. 2003, Sané 2006) could have an effect. This temperature is the optimum for $C$. raciborskii growth (Briand et al. 2004), and could therefore give this species a competitive advantage over other phytoplankton species, as pointed out by Berger et al. (2006). We cannot exclude a possible top-down determinism of this dominance, since high grazing rates, which preferentially affect diatoms and spare C. raciborskii, are found while C. raciborskii is dominant (Arfi et al. 2003, Ka et al. 2006). However, August to October is also a period during which episodes of severe DIN depletion are observed (Arfi et al. 2003). This suggests that the diazotrophic capacity of $C$. raciborskii helps it to cope with low DIN concentrations, accounting for its sudden rise above the background level present during the rest of the year. As evidenced by our in vitro experiments with $\mathrm{N}$-depleted filtered water from Lake Guiers, $C$. raciborskii growth requires the supply of a strong chelating molecule, such as EDTA. EDTA increases the total dissolved $\mathrm{Fe}(\mathrm{III})$, and in particular the potentially bioavailable species of Fe' (Table 4). Since our experiments were carried out within closed systems, they did not provide any information about the bioavailability of iron and chelators in the natural open system of Lake Guiers. We can, however, predict several possible sources. (1) In a lateritic environment, such as that of the lake watershed, the waterflow during the flood season (from July to November) carries huge amounts of particulate iron, oxy-hydroxides mostly similar to goethite and $\mathrm{FeOOH}$, which is probably the most insoluble form of $\mathrm{Fe}(\mathrm{III})$, with $\mathrm{p} K_{\mathrm{s}}$ values ranging from 42 to 44. In this form, iron is definitely not bioavailable. (2) The flux of dissolved reduced iron from the sediment is mainly in the form of $\mathrm{Fe}^{2+}$ (Sarazin et al. 1995, Michard et al. 2001). This results from the mineralization of organic matter when particulate ferric hydroxide is used as an electron acceptor. Since Lake Guiers is very shallow, with virtually permanent winds, the water column is usually well mixed and does not display any thermal or chemical stratification. Hence, as dissolved oxygen is present at the sediment-water interface, the $\mathrm{Fe}^{2+}$ present is readily oxidized into amorphous ferric hydroxide similar to ferrihydrite, the oxidation rate being a function of the oxygen partial pressure and pH (Stumm \& Morgan 1981, Sigg et al. 1992). At a pH of $>8$, the oxidation rate can be considered to be infinite. These authigenic hydroxides (ferrihydrite) are much more soluble than the primary particles of goethite. Fluxes of dissolved reduced iron at the sediment-water interface have been estimated at 2 sampling stations. We used Fick's first law to make these estimations:

$$
F=-\Phi D^{\circ} \operatorname{gradC}
$$

where $\Phi$ is the measured sediment porosity (dimensionless), $D^{\circ}$ is the $\mathrm{Fe}^{2+}$ molecular diffusion coefficient (in $\mathrm{m}^{2} \mathrm{~d}^{-1}$ ) (Li \& Grigory 1974) and gradC is the concen- 
tration gradient (in $\mu \mathrm{mol} \mathrm{m}{ }^{-4}$ ) at the sediment-water interface. This gradient can be computed from the concentration profiles of dissolved Fe(II) in pore water, which were obtained by the 'peepers' method as described in Sarazin et al. (1995). The resulting fluxes range from 140 to $900 \mu \mathrm{mol} \mathrm{m}^{-2} \mathrm{~d}^{-1}$ according to the sampling station and are readily converted into an equivalent amount of ferrihydrite. Mixing by wind can sweep ferrihydrite particles into the trophic zone. (3) Another source of Fe(III) is aeolian, especially when the dominant hot north winds carry huge amounts of goethite-rich dust (Zhu et al. 1997). The photoreduction of iron using UV-B as its main energy source (Rijkenberg et al. 2005) is an efficient process that provides phytoplankton populations with bioavailable iron derived from particulate iron of aeolian origin. This origin is often used to explain how the phytoplankton communities are able to grow in the highly oligotrophic zones of tropical oceans (de Baar \& La Roche 2003). The production of Fe(II) by photoreduction of highly crystallized iron oxides changes the speciation of Fe(III) (Sunda 1989, Rijkenberg et al. 2005). Owing to the very short life-span of $\mathrm{Fe}(\mathrm{II})$ in the photic zone (oversaturated with respect to $\mathrm{O}_{2}$ partial pressure and alkaline $\mathrm{pH}$ as a result of photosynthetic activity in both cases), the re-precipitation of fresh iron (III) hydroxides as ferrihydrite leads to an increase in the total dissolved Fe(III) of several orders of magnitude. This can be computed by simply considering the difference in solubility products of goethite $\left(\mathrm{p} K_{\mathrm{s}} \approx 42\right.$ to 44 ) and ferrihydrite ( $\mathrm{p} K_{\mathrm{s}} \approx 37$ to 38 ). If a thermodynamic equilibrium is reached quickly between the solid and the solution, this difference leads to an increase in the total dissolved Fe(III) ranging from 4 to 6 orders of magnitude (typically from $10^{-26}$ to $10^{-22}$ or $10^{-20} \mathrm{M}$ for $\mathrm{Fe}^{3+}$ at $\mathrm{pH}=8$ ). This process plus inputs from the lake sediment are probably important pathways by which the bioavailable Fe(III) required to sustain Cylindrospermopsis raciborskii growth is replenished.

Ferrihydrite particles carried into the trophic zone need to be dissolved through complexation by an unknown natural chelating agent, represented by EDTA in our experiments. Obviously, in a natural environment, the EDTA, used here as a substitute 'model' molecule, could be replaced by dissolved or colloidal organic matter (van den Berg 1995). In natural waters, the complexing material present will consist of a combination of autochthonous molecules and allochthonous products, such as humic or fulvic acids. Some autochthonous molecules are produced by both bacteria and cyanobacteria. The most efficient molecules with regard to $\mathrm{Fe}(\mathrm{III})$ sequestration are known as siderophores (Wilhelm \& Trick 1994, Parparova \& Yacobi 1998). These very potent chelators have appar- ent complexing constants ranging from $10^{20}$ to $\sim 10^{60}$ (Stumm \& Morgan 1981). We used the colorimetric method of Schwyn \& Neilands (1987) to check whether Cylindrospermopsis raciborskii produced either hydroxamic or catecholic siderophores. Since no obvious colorimetric effect was detected, we can conclude that under our experimental conditions our strain did not produce any kind of siderophore. Humic and related substances are polymers produced during early degradation of plant tissues; their molecular weight is typically between 300 and $30000 \mathrm{~g} \mathrm{~mol}^{-1}$. The main functional groups are phenol-OH and carboxyl-COOH. These macromolecules are able to bind most transition metals and, thus, to retain them in solution (Kogut \& Voelker 2001, Rose \& Waite 2003). For example, we can write for $\mathrm{Fe}(\mathrm{III})$ :

$\mathrm{Fe}(\mathrm{OH})_{3}$ (solid ferrihydrite) $\leftrightarrows \mathrm{Fe}^{3+}+3 \mathrm{OH}^{-}\left(\mathrm{p} K_{\mathrm{s}}=37\right)$ $\mathrm{Fe}^{3+}+$ humic acid $\leftrightarrows \mathrm{Fe}(\mathrm{III})$-complex

This second reaction shifts the first one to the right and increases the solubility of ferrihydrite. This transportation mode could obviously occur during the flood season, when high amounts of dissolved organic carbon are extracted from the soil and the vegetation by rushing water. In many cases, worldwide, estuarine and lacustrine algal blooms have been linked to terrestrial run-off of dissolved organic matter following periods of heavy rainfall (Pearl 1988, Seitzinger et al. 2002). More specifically, blooms of cyanobacteria have been linked to terrestrial organics providing a source of bioavailable iron (Emmenegger et al. 1998, Albert et al. 2005). A seasonal supply of this type, combined with the observed DIN depletion (Arfi et al. 2003), could explain the outbreak of Cylindrospermopsis raciborskii in autumn.

\section{CONCLUSIONS}

From September to November, the water of Lake Guiers is DIN depleted in terms of phytoplankton nutrient requirements. During this period, marked increases in the biomass of heterocystous cyanobacteria are observed, with Cylindrospermopsis raciborskii being amongst the dominant species. Our findings suggest that, during this period, DIN depletion is counterbalanced by the diazotrophy of this cyanobacterium. $\mathrm{N}_{2}$ fixation could be possible as a result of the increase in Fe bioavailability, which itself results from several processes: (1) precipitation of ferrihydrite, which is much more soluble than the primary goethite; and (2) the probable presence of natural organic ligands, carried in by the waterflow during the rainy season, which buffer Fe(III) bioavailability; these ligands were replaced by EDTA in our experiments. This phe- 
nomenon, in which the bioavailability of iron rather than its total abundance is involved in nutrient limitation, has been reported in oceanic and coastal waters (e.g. Morel \& Price 2003, Watkinson et al. 2005). Dissolved organic material released from phytoplankton has been proven to control the solubility and bioavailability of iron (Chen et al. 2004, Lohan et al. 2005), and many of the dissolved organic matter compounds involved in Fe complexation have been described (Butler 1998, 2005). Despite the situation in the western African region, where the soil background is lateritic, and iron is therefore abundant, so far no study has reported any such cascading limitation due to $\mathrm{Fe}$ bioavailability in freshwater from this area.

Cyanobacterial blooms are currently observed in the West African Sahelian zone, and Cylindrospermopsis spp. are often responsible for these proliferations. It is therefore important to find out whether these limitation processes that are at work in Lake Guiers are present in other Sahelian lakes and reservoirs, thus allowing sporadic dominance of heterocystous cyanobacteria. This knowledge could be crucial, for example, in regional water policy planning. Changes in water use within a watershed could result in increased dissolved organic material inputs into reservoirs, leading to cyanobacterial blooms, as has been demonstrated, for example, in coastal areas (Watkinson et al. 2005). In ongoing research our team is attempting to identify the link between human activities and their consequences for the tropical freshwater reservoirs of western Africa and islands in the Indian Ocean.

Acknowledgements. We thank R. Arfi and the IRD staff in Dakar, Senegal, for their unfailing help and support during the field work. We also thank C. Bernard (MNHN-Paris) for providing the PMC 118.02 strain of Cylindrospermopsis raciborskii, and M. Bouvy and P. Cecchi for their comprehensive discussions of the manuscript. This publication is part of the IRD research group CYROCO (UR 167) program, IRD Dakar Senegal.

\section{LITERATURE CITED}

Albert S, O'Neil JM, Udy JW, Ahern KS, O'Sullivan CM, Dennison WC (2005) Blooms of the cyanobacterium Lyngbya majuscula in coastal Queensland, Australia: disparate sites, common factors. Mar Pollut Bull 421:428-437

Arfi R, Ba N, Bouvy M, Corbin C and 7 others (2003) Lac de Guiers (Sénégal). Conditions environnementales et communautés planctoniques. Document Centre IRD, Dakar. Available at www.mpl.ird.fr/flag/data_sans_mot_ de_passe/site_type_ngnith/rapport_guiers.pdf

Berger C, Ba N, Gugger M, Bouvy M, Rusconi F, Couté A, Troussellier M, Bernard C (2006) Seasonal dynamics and toxicity of Cylindrospermopsis raciborskii in Lake Guiers (Senegal, West Africa). FEMS Microbiol Ecol 57(3):355-366

Bernard C, Harvey M, Briand JF, Biré R, Krys S, Fontaine JJ
(2003) Toxicological comparison of diverse Cylindrospermopsis raciborskii strains: evidence of liver damage caused by a French $C$. raciborskii strain. Environ Toxicol 18:176-186

Brand LE, Sunda WG, Guillard RRL (1986) Reduction of marine phytoplankton reproduction rates by copper and cadmium. J Exp Mar Biol Ecol 96:225-250

Briand JF, Humbert JF, Leboulanger C, Bernard C, Dufour P (2004) Cylindrospermopsis raciborskii invasion at midlatitudes: selection, wide physiological tolerance or global warming? J Phycol 40:231-238

Butler A (1998) Acquisition and utilization of transition metal ions by marine organisms. Science 281:207-209

Butler A (2005) Marine siderophores and microbial iron mobilization. Biometals 18:369-374

Chen M, Wang WX, Guo LD (2004) Phase partitioning and solubility of iron in natural seawater controlled by dissolved organic matter. Global Biogeochem Cycles 18: GB4013

Cogels FX (1984) Etude limnologique d'un lac sahélien, le lac de Guiers (Sénégal). PhD dissertation, Fondation Universitaire Luxembourgeoise, Arlon

Cogels FX, Fraboulet-Jussila S, Varis O (2001) Multipurpose use and water quality challenges in Lac de Guiers (Senegal). Water Sci Technol 44:35-46

de Baar HJW, La Roche J (2003) Metals in the oceans; evolution, biology and global change. In: Lamy $F$, Wefer $G$, Mantoura F (eds) Marine scientific frontiers for Europe. Springer-Verlag, Berlin, p 79-105

Dufour P, Berland B (1999) Nutrient control of phytoplanktonic biomass in atoll lagoons and Pacific Ocean waters: studies with factorial enrichment bioassays. J Exp Mar Biol Ecol 234:147-166

Emmenegger L, King DW, Sigg L, Sulzberger B (1998) Oxidation kinetics of $\mathrm{Fe}(\mathrm{II})$ in a eutrophic Swiss lake. Environ Sci Technol 32:2990-2996

Fogg GE (1974) Nitrogen fixation. In: Stewart WDP (ed) Algal physiology and biochemistry. Blackwell, Oxford, p 560-582

Gorham PR, McLachlan J, Hammer UT, Kim WK (1964) Isolation and culture of toxic strains of Anabaena flos-aquae (Lyngb.) de Breb. Verh Int Ver Limnol 15:796-804

Gugger M, Molica R, Le Berre B, Dufour P, Bernard C, Humbert JF (2005) Genetic diversity of Cylindrospermopsis strains (Cyanobacteria) isolated from four continents. Appl Environ Microbiol 71:1097-1100

Hawkins PR, Runnegar MTC, Jackson ARB, Falconer I (1985) Severe hepatotoxicity caused by the tropical cyanobacterium (blue-green alga) Cylindrospermopsis raciborskii (Woloszynska) Seenaya and Subba Raju isolated from a domestic supply reservoir. Appl Environ Microbiol 50: 1292-1295

Istvǎnovics V, Shafik HM, Présing $M$, Juhos S (2000) Growth and phosphate uptake kinetics of the cyanobacterium, Cylindrospermopsis raciborskii (Cyanophyceae) in throughflow cultures. Freshw Biol 43:257-275

Jung J, Jo HJ, Lee SM, Ok YS, Kim JG (2004) Enhancement of biodegradability of EDTA by gamma-ray treatment. J Radioanal Nucl Chem Artic 262:371-374

Ka S, Pagano M, Bâ NG, Bouvy M and 8 others (2006) Effects of man-induced environmental changes on zooplankton communities in Lake Guiers (Senegal, West Africa). Int Rev Hydrobiol (in press)

Kirchman DL (2000) Uptake and regeneration of inorganic nutrients by marine heterotrophic bacteria. In: Kirchman DL (ed) Microbial ecology of the oceans. Wiley-Liss, New York, p 261-288 
Kirchman DL, Suzuki Y, Garside C, Ducklow HW (1991) High turnover rates of dissolved organic carbon during a spring phytoplankton bloom. Nature 352:612-614

Kogut MB, Voelker BM (2001) Strong copper-binding behaviour of terrestrial humic substances in seawater. Environ Sci Technol 35:1149-1156

Leboulanger C, Quiblier C, Dufour P (2006) Rapid assessment of multiple-limiting factors in phytoplankton biomass: bioassays, in vivo chlorophyll a fluorescence, and factorial design. Arch Hydrobiol 166:433-451

Li Y, Gregory S (1974) Diffusion of ions in sea water and deep sea sediments. Geochim Cosmochim Acta 38:703-714

Lohan MC, Crawford DW, Purdie DA, Statham PJ (2005) Iron and zinc enrichments in the northeastern subarctic Pacific: ligand production and zinc availability in response to phytoplankton growth. Limnol Oceanogr 50:1427-1437

Michard G, Sarazin G, Jezequel D, Alberic P, Ogier S (2001) Annual budget of chemical elements in a eutrophic lake, Aydat Lake (Puy de Dôme), France. Hydrobiologia 459: $27-46$

Morel FMM, Price NM (2003) The biogeochemical cycles of trace metals in the oceans. Science 300(5621):944-947

Padisák J (1997) Cylindrospermopsis raciborskii (Woloszynska) Seenayya et Subba Raju, an expanding, highly adaptive cyanobacterium: world wide distribution and review of its ecology. Arch Hydrobiol Suppl 107:563-593

Paerl HW (1988) Nuisance phytoplankton blooms in coastal, estuarine and inland waters. Limnol Oceanogr 33:823-847

Parekh P, Follows MJ, Boyle EA (2004) Decoupling of iron and phosphate in the global ocean. Global Biochem Cycles 19:GB2020. DOI: 10.1029/2004GB002280

Parparova R, Yacobi YZ (1998) Chelatable iron in sub-tropical Lake Kinneret: its seasonal variation and impact on carbon uptake by natural algal assemblages and monoalgal cultures. Aquat Sci 60:157-168

Podda F, Michard G (1994) Mesure colorimétrique de l'alcalinité. CR Acad Sci Paris 319:651-657

Rijkenberg MJA, Fischer AC, Kroon KJ, Gerringa LJA, Timmermans KR, Wolterbeek BT, Baar HJW (2005) The influence of UV irradiation on the photoreduction of iron in the Southern Ocean. Mar Chem 93:119-129

Rose AL, Waite TD (2003) Kinetics of iron complexation by dissolved natural organic matter in estuarine waters. Mar Chem 84:85-103

Sané S (2006) Contrôle environnemental de la production primaire du lac de Guiers au nord du Sénégal. Doctoral thesis, University Cheikh Anta Diop, Dakar

Sarazin G, Gaillard JF, Rabouille C, Philippe L (1995) Organic

Editorial responsibility: Fereidoun Rassoulzadegan (Contributing Editor), Villefranche-sur-Mer, France matter mineralization in the pore water of a eutrophic lake (Aydat Lake, Puy de Dôme, France). Hydrobiologia 315: 95-118

Sarazin G, Michard G, Prévot F (1999) A rapid and accurate method for alkalinity measurements in seawater samples. Water Res 33:290-294

Scbecher WD, McAvoy DC (1991) MINEQL+: a chemical equilibrium program for personal computer. User's manual, Version 2.1.

Schwyn B, Neilands JB (1987) Universal chemical assay for detection and determination of siderophores. Anal Biochem 160:47-56

Seidl M, Huang V, Mouchel JM (1998) Toxicity of combined sewer overflows on river phytoplankton: the role of heavy metals. Environ Pollut 101:107-116

Seitzinger SP, Sanders RW, Styles R (2002) Bioavailability of DON from natural and anthropogenic sources to estuarine plankton. Limnol Oceanogr 47:353-366

Sigg L, Stumm W, Behra P (1992) Chimie des milieux aquatiques. Masson, Paris

Spröber P, Shafik HM, Présing M, Kovács WA, Herodek S (2003) Nitrogen uptake and fixation in the cyanobacterium Cylindrospermopsis raciborskii under different nitrogen conditions. Hydrobiologia 506-509:169-174

Stumm W, Morgan JJ (1981) Aquatic chemistry, an introduction emphasizing chemical equilibria in natural waters, 2nd edn. Wiley Interscience, New York

Sunda WG (1989) Trace metal interactions with marine phytoplankton. Biol Oceanogr 6:411-442

van den Berg CMG (1995) Evidence for organic complexation of iron in seawater. Mar Chem 50:139-157

Várkonyi Z, Zsiros O, Farkas T, Garab G, Gombos Z (2000) The tolerance of cyanobacterium Cylindrospermopsis raciborskii to low-temperature photo-inhibition affected by the induction of polyunsaturated fatty acid synthesis. Biochem Soc Trans 28:892-894

Watkinson AJ, O'Neil JM, Dennison WC (2005) Ecophysiology of the marine cyanobacterium Lyngbya majuscula (Oscillatoriaceae) in Moreton Bay, Australia. Harmful Algae 4:697-715

Wheeler PA, Kirchman DL (1986) Utilization of inorganic and organic nitrogen by bacteria in marine systems. Limnol Oceanogr 31:998-1009

Wilhelm SW, Trick CG (1994) Iron-limited growth of cyanobacteria: multiple siderophore production is a common response. Limnol Oceanogr 39:1979-1984

Zhu XR, Prospero JM, Millero FJ (1997) Diel variability of soluble Fe(II) and soluble total Fe in North African dust in the trade winds at Barbados. J Geophys Res 102:21297-21305

Submitted: December 14, 2005; Accepted: April 21, 2006

Proofs received from author(s): September 19, 2006 